А. М. Антоненко, Н. В. Мережкіна, В. Г. Бардов, П. В. Ставніченко

Національний медичний університет імені О. О. Богомольця, м. Київ

\title{
ДОСВІД ВИКЛАДАННЯ ОКРЕМИХ ПИТАНЬ КЛІМАТОТЕРАПІЇ СТУДЕНТАМ 6 КУРСУ АНГЛОМОВНОЇ ФОРМИ НАВЧАННЯ НА КАФЕДРІ ГІГІЄНИ ТА ЕКОЛОГІЇ НАЦІОНАЛЬНОГО МЕДИЧНОГО УНІВЕРСИТЕТУ ІМЕНІ О. О. БОГОМОЛЬЦЯ
}

\author{
A. M. Antonenko, N. V. Merezhkina, V. G. Bardov, P. V. Stavnichenko \\ O. Bohomolets National Medical University, Kyiv
TEACHING EXPERIENCE OF SOME CLIMATOTHERAPY ISSUES MEDICAL UNIVERSITY \\ FOR 6 COURSE ENGLISH-SPEAKING STUDENTS AT THE HYGIENE \\ AND ECOLOGY DEPARTMENT OF O. O. BOHOMOLETS NATIONAL
}

\begin{abstract}
Мета дослідження - поділитися досвідом викладання окремих тем, зокрема питань кліматотерапії, студентам-іноземцям медичних вузів, що знаходяться на завершальному етапі свого навчання.

Матеріали та методи дослідження. У роботі використано методи аналізу, синтезу та систематизації інформації, статистичні методи. Як джерела інформації використано дані Міністерства освіти і науки України та офіційного сайту НМУ.

Результати й обговорення. Кліматотерапія - це доступний та приємний для пацієнта спосіб лікування, який має виражені терапевтичні та профілактичні властивості, допомагає в лікуванні хронічних та аутоімунних захворювань. Зважаючи на те, що більше 80 \% студентів-іноземців НМУ імені О. О. Богомольця англомовної форми навчання приїхали із країн з жарким кліматом і повернуться туди ж працювати лікарями, більше уваги колектив кафедри гігієни та екології приділяє розгляду питань використання кліматичних курортів саме пустельної та степової зон із метою лікування та профілактики захворювань. Для наочності навчання нами були створені матеріали у вигляді блок-схем, які включають інформацію щодо особливостей кожного типу кліматичних курортів, кліматичних факторів, механізму їх дії, показань та протипоказань до їх використання. Студенти навчаються застосовувати схеми використання кліматичних курортів для лікування і профілактики конкретних захворювань на прикладі ситуаційних задач із детальним описанням клінічної ситуації: анамнезу, симптоматики захворювання, місця проживання та роботи пацієнта тощо.

Висновок. Розроблена кафедрою методологічна база для викладання питань кліматотерапії студентам англомовної форми навчання сприяє отриманню ними необхідних практичних навичок та підвищенню рівня загальної професійної підготовки.
\end{abstract}

Ключові слова: навчання; особливості; студенти-іноземці; кліматотерапія.

The aim of the study - to share our experiences of teaching, including issues of climate therapy, for foreign students of medical universities that are in the final stage of their training.

Materials and Methods. The methods of analysis, synthesis and systematization of information, statistical methods were used in this work. As sources of information data from the Ministry of Education and Science of Ukraine and the official site of NMU were used.

Results and Discussion. Climate therapy - is accessible and enjoyable way to treat a patient that has a pronounced therapeutic and prophylactic properties, helps in the treatment of chronic and autoimmune diseases. Considering the fact that over $80 \%$ of O. O. Bohomolets NMU foreign students came from countries with hot climates and they will back there to work as doctors, staff of the Hygiene and Ecology Department pays more attention to review of the questions of climatic resorts is desert and steppe zones usage for the treatment and prevention of diseases. For descriptive reasons of teaching materials in the form of block diagrams that include information on the characteristics of each type of climatic resorts, climatic factors for use in a particular case, their mechanism of action, indications and contraindications for their use were created by us using guidelines of Uzhhorod University Department of Health Resorts. Students are trained to apply the scheme using climatic resorts for treatment and prevention of specific diseases by the example of situational tasks with a detailed description of the clinical situation, medical history, symptoms of disease, location and operation of the patient, etc.

Conclusion. Given the foregoing, we conclude that the department developed a metodological framework for teaching foreing English-speaking students of climate therapy helps them to obtain necessary practical skills and raising the level of general training.

Key words: education; features; foreign students; climate therapy.

(c) А. М. Антоненко, Н. В. Мережкіна, В. Г. Бардов, П. В. Ставніченко 
Вступ. За даними Міністерства освіти та науки України, в Україні навчається 63906 іноземних студентів із 148 країн світу. 3 них 12950 осіб навчається у Києві, і з кожним роком ця цифра збільшується [1, 2]. Найбільше студентів - це вихідці з Азербайджану (10 313), Туркменистану (9806) та Індії (6138) [2]. Тому великі групи іноземців можна зустріти в Національному технічному університеті України "Київський політехнічний інститут”, Київському національному університеті ім. Т. Шевченка, Національному медичному університеті ім. О. О. Богомольця. Перше місце за кількістю студентів-іноземців займають медичні ВН3 (35,37 \%), а Національний медичний університет займає 10 місце серед усіх університетів України за кількістю таких студентів (1588 осіб) [2, 3]. Слід відмітити, що 18,88 \% усіх студентів-іноземців навчаються англійською мовою [2]. Тільки в 2016 році до НМУ вступило більше 500 студентів-іноземців для навчання англійською мовою. Більше половини з них приїхали з Індії [2, 3].

Мета дослідження - поділитися встановленими нами особливостями та досвідом викладання окремих тем, зокрема питань кліматотерапії, студентам-іноземцям медичних вузів, що знаходяться на завершальному етапі свого навчання.

Матеріали та методи дослідження. У роботі використано методи аналізу, синтезу та систематизації інформації, статистичні методи. Як джерела інформації використано дані Міністерства освіти і науки України та офіційного сайту НМУ.

Результати й обговорення. Одними 3 головних мотивів отримання вищої освіти в Україні для іноземців $є$ якісна академічна школа та рівень отриманих знань. На кафедрі гігієни та екології створені всі необхідні умови для навчання студентів англомовної форми: працюють три англомовні викладачі. Це доценти, кандидати медичних наук, які мають сертифікати проходження університетських курсів англійської мови та сертифікати В2, видано підручник, до кожного заняття розроблені методичні рекомендації.

Хотілося б приділити увагу питанню викладання окремих тем для студентів 6 курсу. Більшість із 19 тем, вивчення яких передбачено на 6 курсі, вже давно увійшли в програму і їх викладання налагоджено роками.

Однією з таких тем, викладанню якої часто приділяється недостатньо уваги, - питання кліматотерапії та кліматопрофілактики. Адже цей доступний та, що не менш важливо, приємний для пацієнта спосіб лікування має виражені терапевтичні та профілактичні властивості, допомагає в лікуванні хронічних та аутоімунних захворювань. Слід зазначити, що при правильному виборі кліматичного курорту для конкретного захворювання протипоказання до його застосування мінімальні.

Зважаючи на те, що більше 80 \% студентів-іноземців НМУ імені О. О. Богомольця англомовної форми навчання приїхали із країн з жарким кліматом i, в подальшому, повернуться туди ж працювати лікарями, більше уваги колектив кафедри гігієни та екології приділяє розгляду питань використання кліматичних курортів саме пустельної та степової зон з метою лікування та профілактики захворювань.

Для наочності навчання нами з використанням методичних рекомендацій [4] були створені матеріали [5] у вигляді блок-схем, які включають інформацію щодо особливостей кожного типу кліматичних курортів, кліматичних факторів для використання в конкретному випадку, механізму їх дії, показань та протипоказань до їх використання.

В таблицях 1 та 2 наведені приклади таких схем.

Таблиця 1. Методика застосування пустельних кліматичних курортів

\begin{tabular}{|l|l|}
\hline Характеристика зони & $\begin{array}{l}\text { Клімат пустель відрізняється тривалим жарким та сухим літом з дуже високою се- } \\
\text { редньою температурою повітря (40-50 ), низькою вологістю (менше } 10 \text { \%), зна- } \\
\text { чною швидкістю руху повітря, інтенсивною сонячною радіацією }\end{array}$ \\
\hline $\begin{array}{l}\text { Кліматичні фактори, що } \\
\text { використовують }\end{array}$ & Температура та вологість повітря, швидкість руху повітря \\
\hline $\begin{array}{l}\text { Механізм дії кліматичних } \\
\text { фактовів }\end{array}$ & $\begin{array}{l}\text { Кліматичні фактори діють на організм через нервово-рефлекторний апарат шкіри і } \\
\text { дихальних шляхів - є природними біостимуляторами організму, нормалізують його } \\
\text { реактивність, підвищують обмін речовин, стимулюють функцію надниркових залоз. } \\
\text { Поєднання високої температури та швидкості руху повітря з низько вологістю } \\
\text { активізує потовиділення, що дозволяє таким альтернативним шляхом виводити з } \\
\text { організму воду та мікроелементи, полегшуючи функціонування нирок }\end{array}$ \\
\hline Показання до застосування & Хронічні запальні захворювання нирок (нефрити) \\
\hline $\begin{array}{l}\text { Протипоказання до засто- } \\
\text { сування }\end{array}$ & $\begin{array}{l}\text { Захворювання серцево-судинної системи з недостатністю кровообігу, гіпертоніч- } \\
\text { на хвороба, запальні та онкологічні захворювання шкіри, загострення будь-якого } \\
\text { хронічного захворювання і гострі захворювання з підвищеною температурою тіла }\end{array}$ \\
\hline Локалізація & Південна Африка (Єгипет, Марокко), Західна Азія (Туреччина, Іран, Лівія) та інші \\
\hline
\end{tabular}


Таблиця 2. Методика застосування степових кліматичних курортів

\begin{tabular}{|l|l|}
\hline Характеристика зони & $\begin{array}{l}\text { Клімат характеризується високою температурою повітря (до 30-35 C) i } \\
\text { різкими їі перепадами вдень та вночі, інтенсивною сонячною інсоляцією } \\
\text { до 0,9 кВт/м², низькою вологістю до 10-25 \%, високою чистотою повітря. } \\
\text { Завдяки наявності трав’яного покриву збільшується відносна вологість } \\
\text { повітря (до 10-25 \%), зменшується його запиленість }\end{array}$ \\
\hline $\begin{array}{l}\text { Кліматичні фактори, що викорис- } \\
\text { товують }\end{array}$ & $\begin{array}{l}\text { Температура та вологість повітря, амплітуда температурних коливань, } \\
\text { чистота повітря }\end{array}$ \\
\hline Механізм дії кліматичних факторів & $\begin{array}{l}\text { Лікувальні ефекти: мукоцидний, секреторний, гіпотензивний, нейроре- } \\
\text { гуляторний }\end{array}$ \\
\hline Показання до застосування & $\begin{array}{l}\text { Хронічний бронхіт (ХОзЛ), трахеїт зі значним виділенням мокротиння, } \\
\text { сухий плеврит, туберкульоз у фазі розсмоктування інфільтратів }\end{array}$ \\
\hline Протипоказання до застосування & $\begin{array}{l}\text { Захворювання серцево-судинної системи з недостатністю кровообігу, } \\
\text { емфізема легень, кавернозний туберкульоз, бронхіальна астма } 3 \text { частими } \\
\text { нападами ядухи }\end{array}$ \\
\hline Локалізація & $\begin{array}{l}\text { Центральна Туреччина, Центральна Азія, півострів Індостан, частина } \\
\text { Індії та інші }\end{array}$ \\
\hline
\end{tabular}

Студенти навчаються застосовувати схеми використання кліматичних курортів для лікування і профілактики конкретних захворювань на прикладі ситуаційних задач із детальним описанням клінічної ситуації: анамнезу, симптоматики захворювання, місця проживання та роботи пацієнта тощо.

Висновок. Таким чином, враховуючи вищевикладене, можна зробити узагальнення, що розроблена кафедрою методологічна база для підготовки та ведення педагогічної роботи зі студентами-іноземцями англомовної форми навчання загалом і викладання питань кліматотерапії, зокрема, дозволяє ефективно підвищувати ступінь засвоєння

\section{Список літератури}

1. Український державний центр міжнародної освіти Міністерства освіти і науки України: Актуальні статистично-аналітичні показники надання освітніх послуг іноземцям [Електронний ресурс]. - Режим доступу : http://intered.com.ua/Актуальні-статистично-аналітичні-показники.

2. Міністерство освіти та науки України [Електронний ресурс]. - Режим доступу : http://mon.gov.ua.

3. Національний медичний університет імені О. О. Богомольця [Електронний ресурс]. - Режим доступу : http://nmu.ua. - Назва з екрана.

\section{References}

1. Ukrayinskyi Derzhavnyi tsentr mizhnarodnoi osvity Ministerstva osvity i nauky Ukrainy: Aktualni statystychnoanalitychni pokaznyky nadannia osvitnikh posluh inozemtsiam [Ukrainian State Center of International Education of Ministry of Education and Science of Ukraine: Recent statistical and analytical indicators of educational services for ними матеріалу, сприяє отриманню необхідних практичних навичок та підвищенню рівня загальної професійної підготовки.

Перспективи подальших досліджень. Поглиблене вивчення особливостей кліматотерапії кожного з регіонів походження студентів на заняттях важливе для їх подальшої професійної діяльності. Для подальшого покращення викладання названих тем необхідно детально вивчити методики та підходи до використання кліматотерапії в інших країнах світу і розглядати вибірково деякі з них на занятті, залежно від країн проживання студентів групи.

4. Санаторно-курортне лікування хворих пульмонологічного профілю : методичні рекомендації / за заг. ред. В. С. Сухан. - Ужгород : Державний вищий навчальний заклад “Ужгородський національний університет”, 2011. - 28 c.

5. Antonenko A. M. Hygienic assessment of the impact of natural and anthropogenic biospheres constituents on human and health population : guidlines for students / A. M. Antonenko, N. V. Merezhkina, V. G. Bardov. - Kyiv : O. O. Bogomolets National Medical University, 2016. 25 p.

foreigners]. intered.com.ua. Retrieved from http://intered. com.ua/Актуальні-статистично-аналітичні-показники/ [in Ukrainian].

2. Ministerstvo osvity i nauky Ukrainy [Ministry of Education and Science of Ukraine]. mon.gov.ua. Retrieved from http://mon.gov.ua [in Ukrainian]. 
3. Natsionalnyi medychnyi universytet imeni O.O. Bohomoltsia [O.O. Bohomolets National Medical University]. nти.иа. Retrieved from http://nmu.ua [in Ukrainian].

4. Suhan, V.S. (Ed.). (2011). Sanatorno-kurortne likuvannia khvorykh pulmonolohichnoho profiliu: metodychni rekomendatsii [Sanatorium treatment of patients with pulmonary diseases: guidelines]. Uzhhorod: Derzhavnyi vyshchyi navchalnyi zaklad "Uzhhorodskyi Natsionalnyi universytet”, kafedra kurortolohii, medychnoi reabilitatsii ta fizioterapii [in Ukrainian].

5. Antonenko, A.M., Merezhkina, N.V., \& Bardov, V.G. (2016). Hygienic assessment of the impact of natural and anthropogenic biospheres' constituents on human and health population. Kyiv: O.O. Bogomolets National Medical University.

Електронна адреса для листування: antonenko1985@ukr.net 